\title{
La cubanidad de Domingo del Monte: entre la insularidad y el hispanismo americano
}

\author{
María Pía BRUNO \\ Instituto de Investigaciones Literarias y Discursivas \\ Universidad Nacional de La Pampa \\ piabruno@yahoo.com.ar
}

\section{RESUMEN}

En 1833 Domingo del Monte — bajo el seudónimo de Ignacio Herrera Dávila — publica en Cuba las Rimas americanas. El título de esta obra nos permite inscribirla tempranamente en la tradición de antologías literarias que tendrán su referente más citado en la América poética (1846) de Juan María Gutiérrez. Pero al mismo tiempo, podemos trazar en la lectura de esta antología algunas relaciones con el primer Americanismo, en tanto proyecto cultural que aunó el pensamiento de los letrados respecto de la identidad americana durante la primera mitad del siglo diecinueve.

Sin embargo, el lugar paradigmático que ocupó Domingo del Monte en el ámbito político y cultural de la isla implica considerar las paradojales relaciones de la Modernidad. Americanismo, insularidad e hispanismo operan, entonces, como coordenadas de análisis de la obra. En este sentido, proponemos leer la antología como un texto en el cual se fraguan de manera singular las tensiones irresueltas en torno a la configuración de un imaginario patriótico; y cuyo tramado permite señalar de qué manera las matrices de identificación cultural complejizan el posicionamiento ideológico que asume Domingo del Monte. Este acercamiento a las Rimas americanas ofrece, al mismo tiempo, una clave de lectura para la obra delmontina.

Palabras clave: Literatura cubana, siglo XIX, Domingo del Monte, Rimas americanas.

The cubanity of Domingo del Monte: between insularity and American hispanicism

\begin{abstract}
In 1833 Domingo del Monte - under the pseudonym of Ignacio Herrera Dávila — published in Cuba the Rimas americanas. The title of this curious anthology allows us to include it in the tradition of American anthologies, whose referent more renowned is the anthology of Juan María Gutiérrez, América poética, 1846. At the same time, we can establish some relationships with the first Americanism, understood as the movement that brought together writers and intellectuals in the debate about the American identity, in the first half of the nineteenth century.

However, it is necessary to recognize that the paradigmatic place of Domingo del Monte in the political and cultural environment of the island, implies to consider the paradoxical
\end{abstract}


relationships of Modernity. Americanism, Insularity and Hispanic are categories used to read and analyze the work of Del Monte. In this perspective, we propose to read the anthology as a text that condenses the tensions unresolved around the Cuban patriotic identity. On the other hand, this text allows that we identify some of the contradictory matrices that expose the ideological position of Domingo del Monte. At the same time, this approach to Rimas americanas offers a reading key to investigate other texts by Domingo del Monte as also traced the projections of his thought in the twentieth century.

Key words: Cuban literature, 19th century, Domingo del Monte, Rimas americanas.

Sumario: 1. Tradición y reformulación del Americanismo en las Rimas americanas. 2. Modulaciones de lo americano en Domingo del Monte. 3. El Caribe y la otredad: pronunciaciones sobre la insularidad hispana, 4. Configuraciones de la enunciación en el "Prólogo" de las Rimas. 5. El romance cubano como puente del archipiélago.

En Hispanoamérica, cuando la mayoría de los emergentes Estados-Nación se debatía en profundas crisis y guerras civiles, Cuba aún colonia, iniciaba un lento pero fructífero recorrido de diferenciación de la metrópoli que se plasmaba en diversos frentes políticos. Este proceso halla un momento de singular eclosión hacia 1830, cuando los letrados criollos vinculados a las ideas modernas de la Ilustración manifiestan un deseo consciente de delimitar la identidad propia de los cubanos, con la intención de reclamar a España el derecho a la autonomía.

En consecuencia, surgen en este período diferentes discursos que dan cuenta de la singularidad de Cuba, es decir, bregan por una búsqueda y definición de aquellos rasgos particulares que mejor expresan la cubanidad. En estas coordenadas debemos situar una serie de hechos cuya significancia se relaciona con la supra intención de indagar y relevar las notas distintivas que permitan configurar un imaginario de la patria cubana. Al respecto, cabe destacar la creación de instituciones que regulan el estudio y la divulgación de la historia local, como la Sociedad Económica de Amigos del País (1831) y la Academia Cubana de Literatura (1834); la creación de la Revista y Repertorio Bimestre de la isla de Cuba (1831-1833) y la fundación de periódicos como El Plantel y El Aguinaldo Habanero, entre otros, que reproducen polémicas y discusiones sobre el ideario patriótico que impactan en la opinión de los lectores.

Asimismo, se publican textos fundamentales que contribuyen a pensar la identidad en términos diferenciadores, como el Diccionario Provincial de Voces Cubanas de Esteban Pichardo y Tapia (1836) y la publicación de Llave del Nuevo mundo, antemural de las Indias Occidentales. La Habana descripta: Noticias de su fundación aumentos y estados manuscrito que concluyó, en 1761, el Regidor perpetuo del Ayuntamiento de La Habana, José Martín Félix de Arrate Acosta. El "descubrimiento" y la lectura que hacen los letrados criollos, miembros de la 
Sociedad Económica Amigos del País, reubica esta obra en la tradición de los textos fundantes de la identidad criolla-cubana.

Por otro lado, se suma a este panorama de impresiones, la publicación en 1831 de las investigaciones que resultan de los viajes exploratorios que lleva adelante Alexander von Humboltd durante 1805 y que configuran un imaginario definido sobre el paisaje natural y social de la isla.

En este contexto de emergencia de discursos sobre la identidad y la patria, Domingo del Monte (1804-1853) tuvo un papel predominante. La fundación de la Revista y Repertorio Bimestre de la Isla de Cuba y la creación de una Academia de Literatura Cubana son dos gestos culturales que impulsa con determinación, a los cuales hay que sumar un tercero: la creación de las tertulias concebidas como espacios singulares de sociabilidad de las letras cubanas en el periodo decimonónico.

Sin embargo, entre 1830 y 1840 , su labor no solo se reduce a una participación activa en diferentes instituciones culturales, como la citada Sociedad Económica; pues a partir de su unión en matrimonio con Rosa Aldama y Alfonso, acontecida en 1834, se enriquece de manera considerable gracias a la posesión de numerosos ingenios y se convierte en una figura influyente en el panorama político y económico de la isla. Recordemos que, precisamente, hacia 1830 Cuba se convierte en el principal exportador de azúcar del Caribe y, el ingenio, tal como lo denomina Antonio Benítez Rojo (1988), opera como una verdadera "célula socio-económica" que organiza la totalidad de la isla.

Cierto es que la inquietud por la configuración de una identidad patriótica no es exclusiva de Domingo del Monte, pero es la centralidad de su figura en el ámbito cultural y político-social de la primera mitad del siglo la que permite reconocer todo un entramado de relaciones letradas: instituciones, espacios de intercambio, publicaciones, etc. que hacen posible proyectar las hipótesis respecto del modus operandi de los letrados y su intervención consciente en la organización de los espacios de la sociabilidad literaria en el periodo concertado. En este sentido, la pertenencia y el rol de Del Monte en el ámbito letrado decimonónico nos permite situar su producción y establecer relaciones pertinentes con el imaginario patriótico que proyecta en sus escritos.

Al respecto, entre los múltiples gestos culturales que impulsa Domingo del Monte, llama particularmente la atención la producción de un romancero que la crítica ha indagado de manera muy tangencial pues, sin dudas, ha sido la narrativa anti-esclavista del periodo la producción más analizada por la crítica (Benítez Rojo 1988; Salvador Bueno 1988; Vera León 1991; Ramos 1996; Civantos 2005; entre otros).

Ahora bien, pese a que Domingo del Monte instó a sus coetáneos y discípulos a la escritura de un romancero con el objeto de difundir de manera cuasi pedagógica ciertos ideales e imágenes sobre la patria que deseaba promover, el romancero delmontino es, en consonancia con la producción del autor, escueto: solo escribió 
cuatro romances que se incluyen en la antología Rimas americanas publicada en 1833.

Esta antología es singular por varias razones. Ante todo, su fecha permite inscribirla tempranamente en la tradición de antologías americanas que, como bien ha explicado Hugo Achugar $(1996,1997)$ constituyen "parnasos fundacionales" con los cuales "los empecinados compiladores" pretenden construir un determinado imaginario de nación. Asimismo, el paradigmático título de esta antología nos convoca a la reflexión respecto del lugar que esta obra tuvo en el primer Americanismo, entendiendo por éste al movimiento letrado continental que expresó durante la primera mitad del siglo diecinueve la voz de poetas, escritores y pensadores en torno a la configuración de la identidad americana.

En este sentido, proponemos leer la antología como una encrucijada de tensiones respecto de la formulación de un imaginario cubano-americano que entra en conflicto con la hispanidad y la insularidad en tanto matrices de identificación cultural.

Detrás de las Rimas americanas asoma la figura de Domingo del Monte. Algunos de sus biógrafos sostienen que fue quien dirigió la edición bajo el seudónimo de Ignacio Herrera Dávila (Andioc Torres 2002). Proponemos, entonces, pensar que el artilugio de enmascaramiento le permitió ser uno de los selectos poetas antologados, pues sus cuatro romances aparecen bajo la falsa autoría del bachiller Toribio Sánchez de Almodóvar. Esta presencia borrada, pero latente en la antología, nos conduce a pensar en las paradojales relaciones de enunciación que asume Domingo del Monte frente a dos órbitas: lo hispano y lo americano. Al mismo tiempo, esa oscilación pendular propia del letrado moderno (Myers 2008) se ve tensionada por una insularidad que atraviesa y define el lugar de enunciación.

Desde esta perspectiva, las Rimas americanas constituyen un texto que posibilita leer el revés del proceso de construcción del parnaso patriótico cubano, en un momento socio-histórico clave signado por la inestabilidad de la Corona española ante la muerte de Fernando VII (1833) y por el ascenso de la sacarocracia cubana, la elite criolla que después de la Revolución de Haití, adquiere en pocos años un poder inusitado en la sociedad colonial y reclama a la metrópoli mayores privilegios.

En las siguientes páginas pretendemos desarrollar algunos aspectos que nos permiten situar el texto en las coordenadas de un hispanismo americano y, al mismo tiempo, señalar los gestos delmontinos que pueden ser leídos como desvíos de la tradición americanista.

\section{Tradición y reformulación del Americanismo en las Rimas americanas}

Hacia el tercer decenio del siglo diecinueve, cuando las Rimas se publican, ya corre detrás un primer decenio de formulación poética americanista que se inicia en 1823 con la silva "Alocución a la poesía" de Andrés Bello. La invocación del poeta a que las musas abandonen Europa para fijarse en América sella un momento 
singular que coincide con la formación reciente en Hispanoamérica de estados independientes. El Americanismo de la primera mitad del siglo diecinueve se propagará, desde entonces, en distintos discursos que promoverán una identificación del hombre con la tierra al acentuar un imaginario de lo peculiar y singular americano (Ardao 1970; Tejada Ripalda 2004). La literatura servirá a estos fines y, por eso, el Americanismo entronca en la tradición de las antologías, definidas como aquellas compilaciones poéticas que constituyeron uno de los varios soportes usados por la clase letrada vinculada al proyecto de Independencia para formular un imaginario de Estado-Nación. En palabras de Achugar, "los primeros de estos libros tuvieron un gesto, pretendieron darle cuerpo de letra a un sentimiento, a una imaginario de nación" (1997: 13). A la tradición ensayística que expresaba el valor de lo americano iniciada por Simón Bolívar, Andrés Bello, José María Torres Caicedo y José Cecilio del Valle, entre otros, se suman las primeras antologías poéticas americanas como La lira Argentina de 1824, El Parnaso Brasileiro de 1829 y El Parnaso Oriental de 1835.

En la configuración de estas antologías, el letrado decimonónico erigió su autoridad al posicionarse como mediador e intérprete de las formas simbólicas (Achugar 1997; Guzman 2009; Pas 2010). El discurso americanista se entretejió tempranamente con esa representación de los hombres de saber, tanto que - como bien observa Carlos Altamirano- "el panteón de hombres elevados se configuró con los héroes de la emancipación y con los héroes del pensamiento" (2008: 16). En el marco de esta tendencia se cristaliza la representación del hombre de letras como apóstol y visionario, que honra a su país con sus obras y lo inspira con su pensamiento y su acción cívica. Esta representación se nutre, en consecuencia, de las imágenes de maestro, mentor y guía para explicar el rol cívico de los letrados, quienes articulan un discurso edificante de la patria americana. Si bien estos hombres de letras explicitan las peculiaridades y diferencias, al mismo tiempo, resaltan elementos comunes, ligadores (históricos, culturales, lingüísticos, religiosos, institucionales, entre otros) que otorgan al continente una identidad supra-nacional.

Ahora bien, las coordenadas ideológicas y estéticas que delimitan la publicación de las Rimas deben pensarse no solo en relación a esta doble tradición del Americanismo y de la emergencia de las antologías literarias americanistas sino, además problematizarse a partir de considerar la singular inscripción territorial y política de Cuba. En primer lugar, porque es una isla que forma parte del archipiélago del Caribe, complejo espacio de relaciones marítimas y comerciales que tuvo un papel central en el desarrollo de la economía europea desde el siglo dieciséis y, porque su situación de colonialidad extendida hasta 1898 suscita necesariamente otros condicionamientos a la formulación de una identidad patriótica. En este sentido, las Rimas se desvían de la tradición de las antologías citadas pues no constituye un texto de la Independencia. No obstante, hay una relación entre publicación y contexto político que se articula en la figura de 
Domingo del Monte, en tanto convergen en él diferentes posiciones de enunciación: pues es integrante de la sacarocracia y de sus intereses económicos que instalan a Cuba como el gran ingenio del Caribe (Benítez Rojo 1988); es asimismo representante de la Ilustración criolla que pregona las luces de la Modernidad al tiempo que mira con recelo lo bárbaro y atávico del sistema esclavista y, por último, se asume como descendiente español, de sangre blanca y cultura latina.

Como ya referimos, hacia 1830 se aprecia un denodado trabajo de las élites criollas cubanas por "descubrir" el país. Este accionar tiene sus precedentes en la labor desarrollada por los primeros americanistas, quienes alentaron el estudio pormenorizado de América con la intención de promover la concepción de una patria grande que se nutre de diferentes identidades. Al respecto, la tentativa de indagar el medio, de definir la historia local y el deseo de aclarar la posición de la cultura respecto de España son aspectos de la autodefinición de la cubanidad criolla que permiten proyectar, primero, un sentimiento de patria concebido éste como el apego afectivo al terruño en el que se ha nacido y, más tarde, desarrollar una conciencia de nación, que involucra otros aspectos tales como la civilidad, la ciudadanía y la constitución de un Estado nacional (Quijada 2004; Rojas 2008). Sin embargo, en el caso cubano, este complejo proceso de diferenciación iniciado por los criollos tuvo un trasfondo económico particular, pues la expansión mercantil que se generó después de la Revolución de Haití (1799-1804) desencadenó una transformación de las relaciones con la metrópoli. La sacarocracia comenzó a exigir mayores derechos a España y a defender sus intereses. Como este reclamo no fue concedido, se suscitó una confrontación con el poder colonial, de ahí surge la necesidad de distinción y autodefinición de la sociedad criolla cubana especialmente la ligada a la producción azucarera - que se expresa hacia el tercer decenio del siglo diecinueve en un conjunto muy diverso de documentos y obras. No obstante, para evitar una confrontación directa, la élite criolla asumió una postura reformista que sostuvo hasta la Guerra Grande (1868-1878).

Las posiciones de enunciación que asume Domingo del Monte en las Rimas evidencian la situacionalidad de su discurso en lo múltiple, pues, como ya explicamos, en él convergen diferentes intereses. En la cubanidad que elabora Domingo del Monte las contradicciones sufren desplazamientos y fraguan una identidad criolla que hunde sus raíces en lo americano pero, al mismo tiempo, es atravesada de manera ineluctable por dos fuerzas polares que tensan y delimitan la identificación: la insularidad y la hispanidad.

Nos preguntamos, entonces, de qué manera Domingo del Monte resuelve en el plano de la escritura esas tensiones y cómo se trasladan a la obra las inquietudes respecto de la configuración de un imaginario patriótico.

\section{Modulaciones de lo americano en Domingo del Monte}

El crítico cubano Salvador Bueno, en los sucesivos trabajos que publica sobre Domingo del Monte y la crítica literaria decimonónica (1954, 1978, 2000), 
concluye que a Del Monte le preocupaba la búsqueda y formación de una tradición y una literatura propias y que, por esta razón, estimulaba el tratamiento de asuntos americanos en la obra de sus contertulios y amigos. Ese "americanismo literario", señala Bueno, "que sería la preocupación constante de los mejores intelectuales de nuestros países latinoamericanos tiene un adecuado teorizador en Domingo del Monte. Como haría años más tarde José Martí, Del Monte insiste en que los dramaturgos de por acá dirijan su atención a las cosas de América, a los asuntos indígenas, a la maravillosa selva y hazañas que llenan nuestra historia" (1979: 37).

Las ideas literarias delmontinas no se explicitan en escritos orgánicos; por el contrario, están diseminadas en diversos textos ensayísticos que sobrevuelan otros temas y también asoman en la valiosa correspondencia que el autor mantiene con poetas y escritores. En este sentido, la recuperación de la voz y del pensamiento de Domingo del Monte requiere la exploración de diferentes textualidades. Por esta misma razón, proponemos acercarnos a las Rimas a través de otras lecturas, como los ensayos críticos y la correspondencia del autor, pues en estos textos advertimos insinuaciones que entendemos constituyen puntos de inflexión que definen su escritura. Leemos estas insinuaciones como marcas tenues de ciertas posturas que hacen a la modernidad latente de Domingo del Monte. Al respecto, la forma en la que se pronuncia sobre lo americano en relación a la literatura no se explicita sino de una manera oblicua, tangencial, que atraviesa con desvíos sus escritos. Un ejemplo de ello es el fragmento tomado de una carta fechada el 14 de octubre de 1826 y dirigida al poeta José María Heredia en la que Del Monte le reclama: "Forma tú la tragedia americana, que tu ingenio la produzca, cándida como sus vírgenes, libre como sus repúblicas y terribles cual Simón y Guadalupe".

Para Salvador Bueno, es claro que Del Monte no pretende una literatura nacional, pero si "americana y criolla" (1978: 38). Desde nuestro análisis de los textos delmontinos delimitamos esta conclusión pues consideramos que Del Monte propone una literatura patriótica que exprese "la verdadera cubanidad", entendida como una matriz simbólica que articula tres diferentes imaginarios: lo criollo, lo español y lo insular. Al mismo tiempo, esta matriz identitaria que se concibe como apego a la tierra excluye el componente negro, lo sitúa en el lugar del extranjero.

Por otro lado, es claro que la pronunciación de lo criollo entronca en lo americano y lo español. En este sentido, el Americanismo de Del Monte no mira hacia el continente ni se piensa en oposición directa con lo hispano, antes bien defiende una criollidad singular que se constituye en la isla desde el siglo diecisiete y que define en uno de sus más notables ensayos - "Caracteres de la literatura española" - como "raza española", término con el que hace confluir el aspecto racial (blanco) con la condición cultural (el idioma y las costumbres peninsulares).

1 Los críticos que han recuperado este extenso ensayo de Domingo del Monte no precisan las fechas de su publicación. 


\section{El Caribe y la otredad: pronunciaciones sobre la insularidad hispana}

El reclamo a mayores derechos impulsado por la sacarocracia cubana se apoyaba, como bien explica Benítez Rojo, en un criollismo diferente en relación a las demás islas factorías del Caribe. Pues mientras en las otras islas no se había desarrollado un apego profundo a la tierra, Cuba ostentaba desde el siglo diecisiete un sector criollo ligado a la industria ilegítima del cuero que se había afincado en los dominios orientales de la isla ${ }^{2}$. A este grupo de criollos más conservadores y dedicado a la ganadería y a otros cultivos como el tabaco, se suman por las contingencias mencionadas los poderosos criollos dueños de ingenios. Si bien las diferencias entre ambos sectores existían, compartían un sentimiento identitario y proclamaban a Cuba como su patria, como la tierra de los antepasados. La isla no era un lugar de veraneo o descanso ni tampoco una gigantesca factoría que se regenteaba desde la península, modelo de producción representado por las Antillas pequeñas $^{3}$. Este sentimiento de pertenencia dirime las posiciones de enunciación de los letrados como Domingo del Monte. Y, si como sostiene Antonio Benítez Rojo (1989), "insularidad y archipiélago son, al mismo tiempo, fragmento y puente", la insularidad que revelan los criollos cubanos hacia 1830 no es de apertura hacia el archipiélago del Caribe, pues las Antillas exponen un escenario de lo que Cuba no deseaba ser: una inmensa factoría que funcionaba con esclavos negros. El miedo a una sublevación similar a la acontecida en Haití caló en los discursos de los filántropos representantes de la Ilustración que bregaban por el fin de la trata negrera, por una abolición paulatina de la esclavitud y por el blanqueamiento de la sociedad como estrategias para superar el mal de la negritud. Para Domingo del Monte y el grupo de letrados que se aglutinaban bajo su figura, Haití era el signo del atraso y la saturación de la barbarie. En este sentido, la mirada del letrado moderno está puesta hacia el interior, hacia una Cuba que denomina "preciosa

2 Benítez Rojo explica que en las sociedades criollas, de tipo ambulatoria, que se generaron en torno al comercio ilegal del cuero, el esclavo negro tuvo un papel mucho más activo.

${ }^{3}$ Este sentimiento de pertenencia se advierte cuando se produjo la revolución azucarera en Cuba y fueron los criollos cubanos (no los españoles) quienes financiaron la modernización del proceso de producción del azúcar, generando una economía de plantación azucarera moderna. En esta coyuntura de enriquecimiento y poder, la sacarocracia y la burguesía cubanas siguieron viviendo en la isla. Si bien las fincas de los ingenios no eran su residencia permanente, pues solo eran utilizadas como recintos para vacacionar, estas familias vivían en las ciudades como La Habana, Matanzas, Santiago de Cuba o Camagüey. Estas clases pudientes tenían dinero y lo gastaban e invertían en Cuba, a diferencia de los plantadores europeos de las Antillas pequeñas (holandesas, francesas o inglesas) que gastaban su dinero en las respectivas metrópolis y que además practicaban el absentismo, encargando sus ingenios a gerentes europeos (Leclercq 2004: 140). 
Antilla" pero que requiere ser civilizada para entrar en la Modernidad y, al mismo tiempo, es una mirada exógena, es una insularidad que se abre al Atlántico, que tiende puentes y mira de cara a las luces de Europa y de Norteamérica pues el sur de América constituye otro extremo donde la barbarie se asienta. Una cita tomada del informe que eleva como secretario de la Sección de Educación de la Sociedad Económica del País en 1836 explicita esta concepción, al mismo tiempo que revela sus preocupaciones:

[104.400 niños y niñas] que sufren en medio de la bastarda riqueza agrícola de la isla de Cuba, la misma carencia de la enseñanza primaria, primer elemento de toda verdadera civilización, que sufren por la barbarie de su estado actual los salvajes del Uruguay . [...] Necedad sería comparar el deplorable estado de la enseñanza primaria de Cuba con el estupendo de los Estados Unidos de América del Norte, la Prusia de Bengala y en sentido contrario con la Rusia, el Portugal y la parte meridional de Francia [...] Un gobierno sabio mirará esta enorme masa de cien mil ignorantes, cien mil revoltosos proletarios, enemigos de la tranquilidad del país, y se interesará sinceramente en la aventura de éste, procurará afianzar en él el orden, difundiendo y costeando escuelas primarias conforme a los progresos intelectuales y morales de la época presente, como lo ha hecho el de la Prusia, y conquistar así a fuerza de luces la paz, la riqueza sólida y la moralidad futura de esta preciosa Antilla (1836: 27).

En este sentido, Cuba es autopercibida por los letrados criollos como una isla hispana en relación constante, y necesaria, con la península: los lazos históricos, culturales y lingüísticos que la ligan de manera ineludible a España posibilitan su civilización, su europeización y su blanqueamiento. En el revés de este espejo, el Caribe constituye un espacio dominado por el salvaje, por la ignorancia y la ignominia es, ni más ni menos, el territorio del Otro (Ferrer 2003; Ramos 1996; Gruner 2010).

La ineluctable insularidad, ese tercer elemento que demarcamos como modulador de la cubanidad en Domingo del Monte, posibilita la figuración de un americanismo criollo o un hispanismo americano que se distancia del continente y permite trazar un arco de relaciones hacia el Atlántico y hacia la Península. De este modo, Del Monte proyecta en sus escritos un espacio de intercambio económico y cultural marcado por la latitud: Cuba, España y Centro-Norteamérica pueden ser analizados como enclaves que delimitan la cubanidad delmontina. Muestra de estas relaciones es el ya citado ensayo "Caracteres..." donde el autor evidencia un conocimiento profundo de la recepción y el estudio de la literatura española en Estados Unidos (Pampín 2015). Asimismo, los abordajes comparativos entre Norteamérica y Cuba en relación a las formas de producción económica y al sistema esclavista desarrollado en las zonas del sur son constantes en la Revista Bimestre Cubana en el periodo en que Domingo del Monte forma parte de equipo editor, como redactor y traductor de los artículos que se reseñan. Por otra parte, 
México constituye un punto de referencia cultural muy importante, recordemos que muchos cubanos coetáneos a Del Monte se exiliaron en estas tierras, el caso más conocido es el del poeta (e íntimo amigo de Del Monte) José María Heredia. Como sostiene Rafael Rojas (2008) la primera generación de exiliados es la que sale de Cuba en los años veinte del siglo diecinueve y que, además de Heredia, incluye a Félix Varela, José Antonio Saco, Gaspar Betancourt Cisneros, Pedro de Rojas, José Teurbe Tolón, José Agustín Arango y los hermanos José Aniceto y Antonio Abad Iznaga. Esta generación, que Rojas denomina "bolivariana" y que estuvo involucrada en las conspiraciones masónicas de los Soles y Rayos de Bolívar y la Gran Legión del Águila Negra, trabajó a favor de la independencia de Cuba desde Nueva York y México, y produjo publicaciones muy valiosas como El Habanero (1825-1826) y El Mensajero Semanal, redactados por Varela y Saco desde Nueva York entre 1828 y 1931, y El Iris, la gran revista literaria emprendida por Heredia y los carbonarios italianos, Florencio Galli y Claudio Linati, publicada en México durante $1826^{4}$.

Las tensiones que se producen en torno a los intentos de definición de la cubanidad pueden rastrearse en las Rimas americanas, un texto paradigmático que nos permite situar y analizar las paradojales posiciones de enunciación asumidas por el autor. En los siguientes apartados proponemos una lectura oblicua de las Rimas que contempla las formulaciones del "Prólogo" y del contenido de la antología a partir de establecer relaciones con otros escritos de Del Monte.

\section{Configuraciones de la enunciación en el "Prólogo" de las Rimas}

Si Ignacio Herrera Dávila, nombre que figura como editor de las Rimas y autor del "Prólogo" no es otro que el propio Del Monte, este desdoblamiento ya pone en escena un sujeto de la enunciación que se enmascara y dice a través de otro. Este decir sin asumir directamente la palabra parece ser el modus operandi de Del Monte, pues tal como afirma Fina García Marruz, "este hombre que apenas escribe, crea siempre una enorme actividad literaria en torno. Su influjo es sutil, jamás directo" (2008: 6).

El "Prólogo" firmado de las Rimas americanas aunque es un texto breve (tan solo cuatro páginas), nos permite explorar la peculiaridad de la voz en escena. El enmascaramiento advertido revela un complejo mecanismo de enunciación en el

\footnotetext{
${ }^{4}$ Rafael Rojas define un segundo momento del exilio que lo enmarca entre mediados de los años treinta, cuando Saco es deportado por el general Tacón, y el estallido de la Guerra de los Diez Años, en 1868. Esas son las décadas de la gran conspiración anexionista en Nueva York y Nueva Orleáns, en la que se destacan escritores como el Lugareño, Cristóbal Madan, José Luis Alfonso, Porfirio Valiente, José Sánchez Iznaga, Juan Clemente Zenea, Miguel Teurbe Tolón y Cirilo Villaverde. Son también los años de la propaganda reformista y antianexionista de Saco desde Europa, de la poesía patriótica de El laúd del desterrado, la célebre antología lírica de 1858 y del periódico La Verdad (1848-1860).
} 
cual la voz portadora de autoridad se desdobla en dos autores: Ignacio Herrera Dávila y el bachiller Toribio Sánchez de Almodóvar, con la intención de legitimar, por un lado, un campo temático típicamente cubano - el que refiere al mundo del guajiro y sus costumbres - y una práctica de escritura - el romance como género privilegiado para expresar la cubanidad ${ }^{5}$. Por otro, legitima su propia posición como autor, pues la inclusión de sus textos en la antología refuerza su condición de escritor americano y lo erige como portavoz del ideario de la patria cubana.

Este primer texto de presentación de la antología se abre con un vocativo: "hispano-americanos", con el cual Del Monte hace visible el lazo cultural lingüístico que liga a España y América. Al respecto, en el erudito estudio sobre los "Caracteres de la literatura española" al que ya hemos hecho referencia, Del Monte expresa: "Otros países que aunque no forman comunión política con España no dejan de ser españoles y lo serán por decreto irrevocable de su destino mientras hablen la lengua castellana" (s/f: 209). Sin embargo, esa hermandad que se pronuncia en el "Prólogo" de las Rimas no es garantía de progreso puesto que el autor observa con "extrañeza" que a pesar de estar dotados de gran ingenio, los hispanoamericanos "no hubiesen adelantado en la poesía durante los años que la cultivaron" (1833: I). Como posible explicación, Del Monte advierte la "servil imitación con que se sujetan los vates de este hemisferio" (I). Dice luego,

Los americanos tomaron por modelo a los poetas españoles porque era les era común el idioma y las costumbres [...] Pero al mismo tiempo que se aprendía el idioma poético de los Garcilasos y Riojas se repetía maquinal y desacertadamente las mismas ideas con la diferencia a favor de los de España, pues ellos cantaban con vigor poético lo que veían y sentían y los de América solo presentaban en sus versos un reflejo descolorido, un eco apagado de las imágenes copiadas del tipo primitivo [...] De la equivocación de estos principios nacieron las innumerables ridiculeces y el desmayo que se notaba en las composiciones de los poetas cisatlánticos (II).

La transcripción de la cita nos permite acceder a las preocupaciones literarias que movilizan a Domingo del Monte. Todo el "Prólogo" se construye en un tono sentencioso y severo que confirma la auto-edificación de autoridad. Por otra parte, la imitación servil a la cual atribuye la causa del atraso poético se remedia cuando la poesía se colma del paisaje peculiar de la isla. Al mismo tiempo, Del Monte insta a los jóvenes poetas para que no caigan en el error de la imitación estéril, y evoca a

${ }^{5}$ Cabe mencionar que el juego de heterónimos es una constante en la literatura de los siglos diecinueve y principios del veinte, por ejemplo, en el ámbito luso hispano podemos reconocer a Joaquim Machado de Assis (1839-1908) y a Fernando Pessoa (1888-1935) como algunos de los escritores que emplearon este recurso. 
dos autores clásicos y canónicos para reforzar el argumento de que es posible producir textos poéticos en los cuales el tono se adapte al paisaje. Dice al respecto:

Quizá la explanación de esta idea servirá a la juventud aplicada para que siga en este bello ramo del saber humano una ancha y brillante senda, por donde pueda adquirir con el tiempo alguno de los laureles inmortales que coronaron las sienes de Homero y Cervantes distinguidos ambos por el tono con que cada cual pintó la fisonomía de su patria (I).

Por otra parte, queremos reparar en las mutaciones que sufre el vocativo empleado para denominar a los mismos sujetos: primero evoca a los escritores "hispanoamericanos", luego, cuando refiere de manera exclusiva a las producciones poéticas producidas en este lado del hemisferio en divergencia con los de España, los denomina "americanos", y por último, se refiere a los poetas "cis-atlánticos". Las tres denominaciones empleadas como cuasi-sinónimos orbitan semánticamente en la triangulación de espacios que definen un área de intercambio y circulación específica. (Centro y Norte)América —el Atlántico - España, delimitan para Del Monte una zona cultural singular que no es posible (o al menos, tan simple) deslindar o distinguir. Este uso "distinto" para significar "lo mismo" refuerza la hipótesis de que en Domingo del Monte y en su proyecto literario cultural se trasunta una experiencia particular del Americanismo que se define por lo insular e hispano.

Con la pregunta dirigida hacia los poetas "¿Por qué no volver la vista a este continente de América?", desde el "Prólogo", Del Monte instala como objeto poético el paisaje americano. La invocación remite sin dudas al poema de Bello. En idéntico gesto, el prologuista convoca a la recuperación de las imágenes americanas que la poesía ha cristalizado: "las gigantescas y tremendas cordilleras, los caudalosos ríos, el Niágara, los diamantes de Brasil, los metales de Méjico y Perú" (III). Como antecedente insoslayable, debemos ubicar el imaginario poético que instala José María Heredia con su "Oda al Niágara" (1824) en la que expresa el amor y el dolor por la ausencia de la patria cubana desde el exilio.

Los poetas que integran la antología, en palabras del enmascarado Del Monte, "han abierto la verdadera senda de la poesía americana", justamente, por dejar de lado la "imitación de las ideas" (IV). Frente al panorama de la servil imitación, la antología se presenta al lector como la primera obra que recupera en Cuba la voz de los "verdaderos poetas americanos", es decir, aquellos que eligen como inspiración $\mathrm{y}$ tema un repertorio local.

El gesto que Del Monte asume con esta antología es construir un parnaso poético americano, en el cual el autor — criollo, blanco y varón- se construye como autoridad retórica y, al mismo tiempo, elabora una categoría identitaria como "universal", que proyecta una "nación ideal" (Achugar 1996). Una de las estrategias de legitimación que deriva del enmascaramiento como autor y editor es la de ubicar 
al Br. Sánchez de Almodóvar al mismo nivel de distinción que el reconocido poeta José María Heredia, de quienes dice que "fueron los primeros que en la isla de Cuba dieron el ejemplo de cantar en sus índicas liras las bellezas físicas y las costumbres de su país" (IV).

Esta afirmación nos permite retomar la preocupación de Del Monte por el hallar el tono cubano, es decir, la manera más adecuada de expresar la cubanidad, pues entiende que detrás de una identidad, hay un tono, una forma de ser pero también de decir lo propio (Salto 2012). Al respecto, en una carta que José Jacinto Milanés le envía en 1836, el poeta matancero expresa:

Así como los romances, canciones, etc. de que se compone la obra son la poesía española de ley, por ser el eco fiel de las costumbres y opiniones del siglo $17^{\circ}$, y anteriores, ¿no podremos en Cuba, popularizando la poesía hacerla un espejo de nuestros usos y de las mil quinientas preocupaciones arraigadas en ellas? ¿No podremos con el arma del ridículo perseguir estas preocupaciones y pulir y mejorar nuestra sociedad en cuanto quepa? ¿De qué sirven esos sonetos, esas odas, esas serias y largas composiciones que no las entiende el pueblo cubano y que maldita es la mella que le hacen? ¿No es mejor que cada composición que se publique en nuestros periódicos, sea en primer lugar breve para que no fastidie, admita un tono sencillo, el que los cubanos tenemos, pinte nuestras cosas para que nos agrade, y a vueltas de lo fácil del verso, del fresco y original colorido, descubra cierta idea moral que sea como el alma de toda ella? (Centón 58).

Las preguntas de Milanés se sustentan en las inquietudes que el propio Del Monte traslada a los escritores más jóvenes que lo rodean y consultan. En este sentido, el fragmento citado nos permite indagar en la preocupación de los escritores por lograr el tono sencillo que caracteriza al pueblo cubano. La respuesta de Domingo del Monte se proyecta en la elaboración de un romancero cubano, pues el profundo conocimiento de la literatura española le permite sostener que el romance es un género ideal para vehiculizar los sentimientos hacia la patria $\mathrm{y}$, al mismo tiempo, es un género popular que trasunta las esferas de la oralidad y la escritura, de manera tal que el pueblo pueda identificar determinadas imágenes edificantes de la cubanidad.

\section{El romance cubano como puente del archipiélago}

Si una antología implica, ante todo, una operación de selección y exclusión, podemos considerar qué atributos de los autores compilados responden al principio rector de la selección. En primer lugar, es llamativa la acotada nómina: solo cuatro autores, contando entre ellos al propio Del Monte, que se esconde bajo el seudónimo de Toribio Sánchez de Almodóvar. La escasez pareciera probar la sentencia del "atraso poético" que se denuncia en el "Prólogo". La idea de "carencia cultural" es, por otra parte, recurrente en los textos delmontinos. La expresión le permite diferenciar ciertas actitudes de sus coetáneos con respecto a algunos 
emprendimientos culturales que lleva adelante, como, por ejemplo, censos educativos y concursos literarios. En los informes que eleva a la Sociedad Económica Amigos del País (1831), aparece la metáfora de la "falta de luces" como sentencia que explica el atraso cultural de la isla.

Por otro lado, advertimos que, aunque las rimas se adjetivan como "americanas", el peso de la elección recae en poetas cubanos contemporáneos a Del Monte: aparte de él, integran la antología el cubano José Policarpo Valdés (1807-1858), Felix Tanco y Bosmoniel (1797-1871), quien nació en Colombia pero vivió toda su vida en Cuba, y el argentino Ventura de la Vega (1807-1865), que residía en las cortes de España. Todos tienen en común la amistad con Domingo del Monte. Por otra parte, el número limitado se asienta en que la obra se presenta como el "Tomo primero", de lo que se deduce que la intención de compilador era publicar tomos sucesivos.

Otro aspecto que consideramos oportuno problematizar son las tensiones estéticas en torno al Neoclasicismo y el incipiente Romanticismo que pueden leerse en la antología. En este sentido, los romances "inventados" por el Bachiller Sánchez de Almodóvar quiebran el sesgo neoclásico que domina en la compilación, pues la mayoría de los poemas seleccionados son odas, elegías, sonetos y versos sáficos. Los postulados de Vitier en la "Quinta Lección" de Lo cubano en la poesía, ayudan a pensar otra tensión: lo culto y lo popular en relación a las estéticas que enmarcan la producción delmontina. Para el crítico, los poetas populares son los poetas románticos que integran el paisaje natural de la isla como objeto poético. No obstante, coincidimos con Vitier cuando afirma que Domingo del Monte no es un poeta popular, no puede serlo por su condición de erudito ni tampoco por el alcance y la difusión de su obra. Lo de Del Monte constituye un proyecto de escritura consciente, mediante el cual pretende moralizar y educar al pueblo cubano. Postulamos entonces que Domingo del Monte no solo elige ("equivocadamente", según el propio Vitier) el romance, sino que en términos de Roger Chartier (1998), se "apropia" del género y lo usa para configurar un imaginario determinado de la cubanidad que pretende sea asumido y reproducido por el pueblo. En este sentido, Del Monte tiene una visión de la literatura como portadora de ciertos valores morales y pedagógicos, que se aproxima más a los postulados estéticos del Neoclasicismo, pero al mismo tiempo, pregona la revalorización del poeta como cantor de lo local y la exaltación de la naturaleza y su influencia en la subjetividad creadora, rasgos que se identifican de manera más general con el Romanticismo (Lowy y Sayre 2008).

Aunque Del Monte evidentemente reconociera una extensa tradición culta del romance, en esta composición de la antología, sus textos irrumpen como un género romántico, en el cual el tono se adapta al paisaje. Este principiar por la naturaleza se corresponde para Cintio Vitier con un proceso paulatino de interiorización del "modo de ser cubano". "Primero fue la peculiaridad de la naturaleza de la isla", señala Vitier en Lo cubano en la poesía (1958), "lo cubano se revela, por la poesía, 
en grados cada vez más distintos y luminosos. No olvidemos [advierte el autor] que el fondo natural es decisivo para entender las configuraciones del carácter, el sentimiento y el espíritu" (29). Ahora bien, si la patria debe ser entendida en esta etapa de formación de la identidad como la interiorización de la naturaleza, ¿qué tipo de representación de la naturaleza se proyecta en el romancero delmontino que integra las Rimas americanas?

Para responder este interrogante proponemos leer los cuatro romances del Domingo del Monte como una poética que articula tres elementos demarcadores de la identidad patriótica: la naturaleza, la raza y la memoria. El orden de presentación de los romances permite pensar en un imaginario identitario que se elabora en capas, de modo que cada romance funciona como integrador de un repertorio de imágenes y metáforas ya semantizadas en el precedente. El montero de la sabana", "El desterrado del hato", "El guajiro" y "La Patria", tal el orden de presentación, conforman un parnaso de la patria, de manera tal que ya desde los títulos es posible identificar campos semánticos específicos mediante los cuales se elaboran ciertas metáforas de pertenencia que promueven una determinada idea de patria: criolla, blanca y cubana. En los dos primeros romances - "El montero de la sabana" y "El desterrado del hato"- es evidente la construcción de una naturaleza como paisaje, es decir, la elaboración literaria de una naturaleza que se interioriza en los sujetos. Ya en el tercer romance, "El guajiro", aparece identificado el sujeto en el cual se depositan los rasgos de la patria. Por último, en el romance titulado "La patria" se asimila los elementos anteriores, pues en esta composición de 83 versos convergen la naturaleza como paisaje, el guajiro y la simbolización del sentimiento patrio ligado al destierro. En términos de Rafael Rojas (2008), podríamos sostener que en el romance "La Patria" operan las tres metáforas que posibilitan explicar la construcción de la nacionalidad cubana. La tierra, la sangre y la memoria constituyen entonces entidades metafóricas que pueden reconocerse en lo profundo del poema.

El tema central de este romance es el lamento por la patria perdida (o dejada). Un destierro aparece como tópico para explicar el sentimiento patrio ${ }^{6}$. El romance

${ }^{6}$ El destierro es un tópico literario plausible de rastrearse desde la Antigüedad clásica, pero en la literatura castellana, es el destierro que sufre el Cid Campeador el que instala el desarraigo de la patria como el peor de los castigos. La idea del destierro está presente, además, en el contexto político en el cual Domingo del Monte produce su obra, pues muchos de sus contemporáneos y allegados son condenados al destierro, tales los casos de José Antonio Saco y el poeta José María Heredia. Este será quien instale en su poemario el tema del dolor por el destierro que sufre en 1823. En sus titulados "Poemas patrióticos", entre los cuales se destaca "El himno del desterrado" (1825) y "A Emilia", (1824) el tema central es la nostalgia generada por el destierro. De 1824 es también la célebre oda al "Niágara", en la cual aparece la palma como símbolo de la patria añorada. El tema del destierro vuelve a ser tratado poéticamente cuando a mediados del siglo, en 1858, un grupo 
se inicia con una décima, bajo la cual se presenta la voz quejosa del guajiro, en la que de inmediato se presenta la comparación con la tierra de Castilla. Por otro lado, la décima que inicia la composición es una invocación, recurso característico del romancero tradicional:

-iMal hayas tú, Manzanares,

El de las ondas mezquino

Mal haya el que a Mantua vino,

Dejando el patrio Almendares!

¡Mal haya el que sus palmares

Y su floreciente orilla

Y su cielo donde brilla

Siempre azul y la rosa

Trocó por esta enojosa

Tierra helada de Castilla! (1-10)

Las figuraciones sobre lo nacional se elaboran en campos semánticos que refuerzan el contraste entre Cuba y Castilla: "brilla", "azul" y "rosa", como elementos que ponderan la calidez se oponen a "enojosa tierra helada". Si en los romances anteriores, el atributo de lo "patrio" adjetivaba elementos como el "machete", en este caso, "patria" es la tierra misma, el suelo donde se ha nacido, "Almendares". El destierro implica, por lo tanto, su abandono.

Por otro lado, la identidad patriótica se construye a partir de la contemplación del paisaje. Pero, en este romance se trata de un paisaje que no se corresponde con lo que los ojos quisieran ver:
Así mirando a la sierra
Del nevado Guadarrama,
Maldice de su fortuna
Un sitiero de Managua.
Por influjos de su estrella,
Que siempre la hubo contraria
En las dehesas se mira
De la más remota España.
Por la aterida ribera
Los ojos del triste vagan

de escritores exiliados reúne su obra poética en la antología El laúd del desterrado que se edita en Nueva York. Sobre finales del siglo diecinueve, José Martí también abordará la temática del destierro en su poemario Flores del destierro (1878-1895). En la literatura del siglo veinte, exilio y destierro operan como tópicos que fundan toda una línea de producción discursiva, por citar solo un ejemplo, traemos a mención el caso de Severo Sarduy y su emblemático ensayo Exiliado de sí mismo publicado en El País (España) en 1992. 
Y en vano busca por ella

Las flores de su sabana. (11-23)

En consecuencia, lo que emerge es la evocación del paisaje; el recuerdo opera como instancia que posibilita la permanencia en la tierra amada. La mirada también se desdobla; hay, por un lado, una mirada errática, perdida, pues los ojos del sitiero triste "vagan y en vano buscan", pero al mismo tiempo, hay una mirada interna, que recupera el paisaje cubano y lo convierte en anhelo: "En vano descubrir quiere/los árboles de su patria/ ¡ay qué solo mira el triste/ marchita, incógnita planta!” (24-27). El último verso del fragmento transcripto permite ejemplificar la extrañeza que le provoca al sujeto desterrado esa naturaleza de España, a la que se suma el sentimiento de rechazo:

\author{
Yermo el prado, turbio el río \\ La natura desmayada, \\ ¡cuán distinto cuadro ofrecen \\ Del de su nativa estancia! \\ Allí todo es verde pompa, \\ Todas son silvestres galas, \\ Y las auroras de enero \\ Con las de abril se igualan (32-39)
}

Este romance es importante en función del ideario patriótico de Domingo del Monte pues instala de forma explícita la diferencia con España. No solo la naturaleza es diferente, el clima cálido aparece como un elemento central de la matriz simbólica de Cuba. Si bien sobre finales del siglo diecinueve y principios del veinte, en concordancia con la mirada determinista - naturalista se desarrollan una serie de ensayos en los cuales el clima aparece como un factor que influye (negativamente) en las condiciones sociales que se gestan en el Caribe, es de notar que en esta temprana configuración identitaria el clima cálido se connota de manera positiva, y contribuye al imaginario de "isla paradisíaca".

La naturaleza como paisaje y el paisaje como evocación generan un doble desplazamiento simbólico, y podríamos decir que las metáforas de la tierra y de la memoria se superponen, pues es la metáfora de la memoria la que alimenta a la de la tierra, ya que es la tierra en ausencia la que se vuelve memoria y se torna presente a través de la escritura. Al mismo tiempo, ambas metáforas sucumben en la de la sangre y, en consecuencia, el guajiro emerge como la figuración sobre la cual se repliegan estas dos entidades.

En todo el romance, la naturaleza es doblemente "extrañada", porque el sujeto que extraña y añora una naturaleza — la cubana - al mismo tiempo, extraña y desconoce la otra, la naturaleza española. La comparación se convierte en el recurso retórico que organiza la significación de la tierra en tanto paisaje rememorado: 


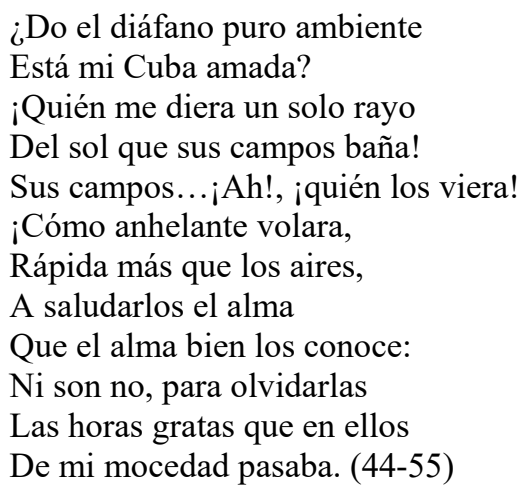

El tono nostálgico se construye además con versos exclamativos tales como "iQuién me diera un solo rayo / del sol que sus campos baña!". Es de notar que la presencia de este recurso pone en evidencia el constante intertexto poético con el romancero tradicional.

En el fragmento citado, el verso "Que el alma bien los conoce" articula dos espacios que podrían oponerse: el del conocimiento con el del sentimiento. Pero la tensión se resuelve porque, en lo que refiere al conocimiento de la patria, es el sujeto nativo el que más sabe y, al mismo tiempo, el que más "siente" esa tierra. También en esta mención del alma que conoce podríamos advertir un tópico romántico que vincula sujeto y tierra en una relación primigenia y originaria. En síntesis, se elabora un paisaje que se peculiariza frente al español a partir del conocimiento sobre el propio espacio natural que tienen los cubanos ${ }^{7}$.

En el romance "La Patria", la tierra idealizada es el campo cubano, sin embargo, la referencia a la naturaleza no se agota en la evocación. En este sentido, en el romance opera otro desdoblamiento: pues a la naturaleza idealizada que es objeto de contemplación se opone una naturaleza explotada. El campo cubano no es solo el espacio donde el guajiro crece y disfruta de su ocio, es también el lugar de trabajo.

En consecuencia, el romancero se ofrece como un espacio simbólico en el que se conjugan las intenciones ideológicas de la elite criolla ilustrada. La naturaleza explotada es el cañaveral fagocitado por la poderosa industria del ingenio. El campo, en tanto imaginario condensador de representaciones transita un doble proceso de configuración. Por un lado, se constituye como espacio literario, como topos romántico. Pero al mismo tiempo, en ese topos se expresan las condiciones materiales históricas, razón por la cual, ese espacio se complejiza ya sea como

${ }^{7}$ José Martí, en el ensayo Nuestra América (1891) -texto paradigmática de la identidad cubana- revalorizará la relación de conocimiento de la tierra que tiene el "hombre natural" y propondrá la fórmula del (conocer lo autóctono para constituir el buen gobierno. 
espacio que se apropia y tiene un valor mercantil, ligado al trabajo, o como espacio puro y virgen, evocado desde una mirada ociosa. A su vez, la referencia a la apropiación exige otro desdoblamiento que conlleva también una carga valorativa. En los romances se distingue entre la faena manual, esforzada del guajiro que trabaja la tierra y el trabajo industrial del ingenio donde se expone la explotación de la tierra, pero también de los cuerpos.

¿Que el viento sonando halaga...
Unico son que se oyera
En ti, mi inocente estancia!
Que nunca escuchar yo pude
Sin que hirviese en ira le alma
El bárbaro atroz chasquido
Del látigo en carne esclava.
Sólo el sudor de mi frente
Libre, enhiesta, muy honrada,
De mis sembrados surcos
Regó con sus gotas santas...
Y más prefiero orgulloso
Pobre vivir más sin mancha,
Que no en opulencia infame
A infame precio comprada (65-79)

Las metáforas de la tierra se desdoblan en dos variantes: la "tierra trabajada" se opone a la "tierra explotada", la marca de distinción está en el uso de la tierra y en los intereses de los sujetos. Mientras que la primera metáfora condensa una carga positiva, como el lugar donde el guajiro reside, en convivencia armónica con la naturaleza; la segunda expone la crueldad del ingenio y la esclavitud como síntoma de barbarie.

En los romances donde la naturaleza romántica es paisaje ocioso que se recuerda o anhela, o tal vez "espacio amoroso" que circunscribe las historias de amor entre los guajiros, opera una retórica de la enumeración y de la descripción. Por el contrario, en los romances donde la naturaleza es espacio explotado, la construcción de los versos adquiere una dinámica que reposa en las acciones y se emplean estrategias como la repetición para dar cuenta de la condición de sometimiento de los hombres en el ingenio. Al respecto, es significativo que en el romance "La Patria", Domingo del Monte mencione la esclavitud, pues la postura que tenía respecto de la trata era muy compleja, oscilaba entre la justificación, "un mal necesario" y que "redime a una raza inferior", y el rechazo filantrópico propio de la Ilustración. En este romance, en la voz del guajiro se expresa la conmoción que causa en su alma la esclavitud: "que nunca escuchar yo pude / sin que me hirviese en ira el alma/ el bárbaro atroz chasquido / del látigo en carne esclava". La metonimia desplaza el significante "carne" por "cuerpo", y luego "cuerpo" por 
"esclavo", y en el juego que esta distancia genera, éste último, el esclavo, termina por convertirse solo en una evocación. Incluso, la referencia al sonido del látigo, al que opone el son, juega también en un plano del recuerdo. En la "inocente" estancia solo se escucha el ruido "natural" del viento. La metáfora de la memoria vuelve a intervenir para dotar de otro sentido al espacio natural en relación al trabajo del sujeto: "Solo el sudor de mi frente / libre, enhiesta, muy honrada / de mis sembrados los surcos/ regó con sus gotas santas" (72-72).

De este modo, en correspondencia con la intención de configurar un imaginario patriótico, y en relación inmediata con un objetivo formador y edificante, en los romances se demarca un doble proceso de significación positiva. Por un lado, un tipo social como el referente máximo de cubanidad, "el guajiro". Así, el sujeto nacional imaginado por el discurso de los reformistas modernizadores, como Domingo del Monte, se articula en términos raciales proponiendo al criollo blanco como emblema de cubanidad. Por otro lado, demarca un modelo económico que promueve el trabajo asalariado, sustentado por las bases del discurso abolicionista. Según la visión de los letrados reformistas, este doble proceso conllevaría a la solución del problema de la heterogeneidad racial en la isla ${ }^{8}$.

En este sentido, el análisis del corpus de romances delmontinos que integran las Rimas americanas expone las tensiones en torno a la configuración de la cubanidad, tal la concibe el autor. Los romances analizados en el contexto de emergencia y situados en una antología exponen un complejo proceso de alianzas y rechazos. Por un lado, sugiere a sus contertulios el uso del romance, un género permeable, que arrastra una antigua tradición hispana y lo satura de imágenes de Cuba: guajiros y guajiras, hateros que recorren los montes y la sabana, el mar y el clima cálido, los tabacales, el ingenio con los esclavos y los mayorales, en fin, cubaniza el romancero, y en un proceso mayor, lo americaniza. Pero esa alianza lingüísticoliteraria constituida desde la elección del género se convierte en rechazo o distancia si se analizan las imágenes metafóricas elaboradas en cuatro los romances.

Por otro lado, el guajiro que une en su simbología tres referentes: racial (blanco), cultural (criollo-español) y económico (trabajo ligado a la tierra) expone, al mismo tiempo, las diferencias irreductibles con el negro, en tanto sujeto/objeto que contamina, atemoriza y acecha el espacio sociocultural-económico. No obstante, advertimos también que la metaforización del espacio no es unívoca, por el contrario, los romances exponen una serie de desplazamientos de las imágenes de la tierra que van desde el paisaje idílico añorado en el exilio, a la naturaleza romántica

\footnotetext{
${ }^{8} \mathrm{Al}$ respecto, uno de los ensayos más importantes de José Antonio Saco (amigo de Del Monte pero mucho más explícito y radical en sus posturas) es "La supresión del tráfico de esclavo africanos en la isla de Cuba, examinada con relación a su agricultura y a su seguridad" (1845).
} 
que acompaña las aventuras del guajiro, para desembocar en una tierra explotada y fagocitada por el ingenio.

Es por ello que la elección de este género como vehiculizador de la identidad patriótica no es casual. Aunque no exista un texto en el cual Domingo del Monte así lo explicite, el romance opera como puente de la insularidad que hermana a Cuba con España y en ese enlace cultural, Cuba torna plausible su reclamo de autonomía. El romance sutura las tensiones irresueltas entre lo americano y lo hispano, y más aún, hace posible la formulación de la identidad de la patria cubana al conciliar tradición y Modernidad.

\section{BIBLIOGRAFÍA}

ACHUGAR, Hugo.

1997 "Parnasos fundacionales: Letra, Nación y Estado en el siglo XIX", Iberoamericana, vol. LXIII, $\mathrm{n}^{\circ} 178-179$, pp. 13-31.

1996 "El parnaso es la nación o reflexiones a propósito de la lectura y el simulacro", en Esplendores y miserias del siglo XIX: cultura y sociedad en América Latina. Beatriz González Stephan (coord.). Caracas: Monte Ávila Editores, pp. 53-72.

ANDIOC TORRES, Shopie.

2002 "Presentación", en Centón epistolario de Domingo del Monte. La Habana: Imagen Contemporánea, pp. V-XXXIX.

ARDAO, Arturo.

1970 Rodó, su americanismo. Montevideo: Biblioteca de Marcha. BELLO, Andrés.

1823 [1883] "Alocución a la poesía", en Obras completas de Don Andrés Bello. Santiago de Chile: Imprenta de Pedro Ramírez, pp.38-61.

BENÍTEZ RoJo, Antonio.

1989 La isla que se repite: el Caribe y la perspectiva posmoderna. Hanover: Ediciones del Norte.

1988 "Azúcar/poder/literatura", Cuadernos Hispanoamericanos, vol. 451-2, pp. 195-215.

BRUNO, María Pía.

2010 "Imágenes de la patria en el romancero cubano (1830-1880)", en Memorias del silencio. Literaturas en el Caribe $y$ en Centroamérica. Graciela Salto (ed.). Buenos Aires: Corregidor, pp.151-180.

2009 "Configuración de la patria y de las letras cubanas en el siglo XIX", Anclajes, vol. XIII, pp. 41-59. 
BUENO, Salvador.

2000 Ensayos críticos de Domingo del Monte. La Habana: Editorial Pablo de la Torriente.

1999 Costumbristas cubanos del siglo XIX, selección, prólogo, cronología y bibliografía Salvador Bueno. Caracas: Ayacucho.

1979 La crítica literaria cubana del siglo XIX. La Habana: Letras Cubanas.

1954 Las ideas literarias de Domingo del Monte. La Habana: Comisión Nacional Cubana de la UNESCO.

Civantos, Christina.

2005 "Pechos de leche, oro y sangre: Las circulaciones del objeto y el sujeto en Cecilia Valdés", en Revista Iberoamericana, vol. LXX, $\mathrm{n}^{\circ}$ 211, pp. 505-519.

CHARTIER, Roger.

1998 "Lecturas y lectores populares desde el Renacimiento hasta la época clásica", en Historia de la lectura en el mundo occidental. Madrid: Taurus, pp. 415-434.

Del MonTE, Domingo.

2002 Centón Epistolario, vol. 2. La Habana: Imagen Contemporánea.

1833 "El Montero de la sabana", "El desterrado del hato", "El Guajiro", "La Patria", en Rimas americanas. Ignacio Herrera Dávila (ed.). La Habana: Imprenta de Palmer.

1829-1831 "Informes y exposiciones pedagógicos. Exposición de las tareas de la Comisión Permanente de Literatura de la Sociedad Económica Amigos del País", en Escritos de Domingo del Monte (1929). José Antonio Fernández de Castro (ed.). La Habana: Cultural. Versión completa University of Florida Digital Collections, University of Florida.

S/F "Caracteres de la literatura española", en Escritos de Domingo del Monte (1929). José Antonio Fernández de Castro (ed.). La Habana, Cultural. Versión completa University of Florida Digital Collections, University of Florida.

FERRER, Ada.

2003 "Noticias de Haití en Cuba", Revista de Indias, vol. LXIII, n²29, pp. 675-694.

GARCÍA MARRUZ, Fina.

2008 Estudios Delmontinos. La Habana: Unión.

GRÜNER, Eduardo.

2010 La oscuridad y las luces. Capitalismo, cultura y revolución. Buenos Aires: Edhasa. 
GUZMÁN, Diana Paola.

2009 "Antologías poéticas: los dueños de la palabra en el siglo XIX", Estudios de literatura colombiana, $\mathrm{n}^{\mathrm{o}}$ 25, pp.90-106.

HERRERA DÁVILA, Ignacio.

1833 Rimas americanas. La Habana: Imprenta de Palmer.

LECLERCQ, Cécile.

2004 El lagarto en busca de una identidad. Madrid: VervuertIberoamericana.

MYERS, Jorge.

2008 "El letrado patriota: los hombres de letras hispanoamericanos en la encrucijada del colapso del imperio español en América", en Historia de los intelectuales en América Latina. Vol. I. La ciudad letrada, de la conquista al modernismo. Carlos Altamirano (dir.) y Jorge Myers (ed.). Buenos Aires: Katz, pp.122-143.

RAMOS, Julio.

1996 Paradojas de la letra. Caracas: Excultura.

1989 Desencuentros de la modernidad en América Latina. México: Fondo de Cultura Económica.

ROJAS, Rafael.

2009 "El mar de los desterrados", La Habana Elegante. Segunda época, $\mathrm{n}^{\circ}$ 46. Web, consultado el 13 de agosto de 2014.

2008 Motivos de Anteo. Patria y nación en la historia intelectual de Cuba. Madrid: Colibrí.

PAMPíN, María Fernanda.

2015 "Entre imperios. Lecturas norteamericanas en el siglo XIX cubano", en Actas del II Congreso Internacional El Caribe en sus Literaturas y Culturas-8 al 10 de abril 2015-Córdoba: Universidad Nacional de Córdoba, pp. 216-222.

PAS, Hernán.

2010 "La crítica editada. Juan María Gutiérrez y la América poética", Orbis Tertius, vol. XV, $\mathrm{n}^{\circ} 16$ pp. 1-12.

PICHARDO Y TAPIA, Esteban.

1836 Diccionario provincial casi razonado de vozes cubanas. Versión digital de la tercera edición 1862. University of Toronto: Robarts Library.

QUIJADA, Mónica.

2004 "QQué nación? Dinámicas y dicotomías de la nación en el imaginario hispanoamericano del siglo XIX", en Inventando la nación. Iberoamérica Siglo XIX. Antonio Annino y FrançoisXavier Guerra (coords.) México: Fondo de Cultura Económica, pp. 287-315. 
SALTO, Graciela.

2012 "Nuevos tonos de antiguas voces cubanas: actualizaciones de la memoria oral" en Ínsulas y poéticas. Figuraciones literarias en el Caribe. Buenos Aires: Biblos, pp. 211-224.

TEJADA RIPALDA, Luis.

2004 "El americanismo. Consideraciones sobre el nacionalismo continental latinoamericano", Investigaciones sociales, vol. VIII, $\mathrm{n}^{\mathrm{o}} 12$, pp. 167-200.

VERA-LEÓN, Antonio.

2001 "Juan Francisco Manzano: el estilo bárbaro de la nación", Hispamérica, vol. XX, nº 60, pp. 4-22. 